\title{
Leftover Spaces for the Mitigation of Urban Heat Island in Municipal Beirut
}

\author{
Noushig Kaloustian ${ }^{1 *}$, David Aouad ${ }^{2 *}$, Gabriele Battista ${ }^{3}$ and Michele Zinzi ${ }^{4}$ \\ 1 Lebanese American University, Department of Natural Sciences, Beirut, Lebanon; noushigk@gmail.com \\ 2 Lebanese American University, Department of Architecture and Design, Beirut, Lebanon; \\ david.awad@lau.edu.lb \\ 3 University of Roma Tre, Department of Engineering, Rome, Italy; gabriele.battista@uniroma3.it \\ 4 ENEA, Rome, Italy; michele.zinzi@enea.it \\ * Correspondence: noushigk@gmail.com; david.awad@lau.edu.lb Tel.: +961-70-126329/+961-3-721794
}

\begin{abstract}
The Urban Heat Island (UHI) is one of the more serious consequences of urbanization resulting in impacts on thermal comfort levels, heat stress, and even mortality. For Municipal Beirut, implementation of "cool" surface materials and green spaces have been recommended to counterbalance the UHI. This paper builds on previous findings on the topic of non-constructible parcels within the district of Bachoura in Municipal Beirut and examines the possibility of implementing "cool" surface or paving materials and urban vegetation which can improve thermal conditions especially during the summer period and with the viewto project the positive findings of this case study to the entire Municipal Beirut area. A numerical analysis using ENVI-met 4.0 investigates the thermal performance of these non-constructibles further to implementation of high reflective surfaces and urban vegetation within a broad neighborhood scale in Bachoura. Results show reductions in ambient temperatures up to $1 \mathrm{~K}$ on a summer day.. Within the framework of an integrated approach to planning, this form of urban acupuncture aims for substantial UHI reduction. Energy performance of buildings further to implementation of these mitigation measures is also recommended for future studies and to validate the findings in this paper.
\end{abstract}

Keywords: urban heat island; non-constructible parcels; cool surfaces; urban vegetation; envi-met; mitigation measures; beirut

\section{Introduction}

Today, 54 per cent of the world's population lives in urban areas, a proportion that is expected to increase to 66 per cent by 2050. With increasing urbanization trends, where natural surfaces are replaced by impermeable surfaces, stresses on the surrounding urban temperatures are escalating. This urban warming, or urban heat island (UHI), is the ability of a town or city to generate more heat than its surrounding suburban counterparts and is connected to impacts on thermal comfort levels, health and even mortality of urban dwellers. With climate change and increasing summer heat waves, the potential means by which the consequences of the UHI can be adapted to and mitigated to build more resilient cities is a topic of much research and discussion worldwide. In fact, counterbalancing the effects of urban heat island is a major priority for the scientific community [1].

Municipal Beirut, with approximately 21,000 inhabitants $/ \mathrm{km}^{2}[2,3]$ is a densely populated city, while covering a relatively small surface area of about $20 \mathrm{~km}^{2}$.

The major master plans Beirut was subject to throughout its history, such as the Danger Brothers Scheme in 1932 and the Ecochard scheme in 1943 and 1964 (Figure 1), combined with an outdated laws and regulations system that manages urban operations, have enriched the urban fabric of Municipal Beirut with a non-negligible number of non-constructible parcels [4]. They are leftover spaces found in the shape of small vacant or built spaces in between buildings or around corners. Since 1954, with the introduction of Article 5 of the decree $n^{\circ}$ 6285/54, Lebanon's Construction's Law 
has acknowledged and defined non-constructible surfaces as such: a) residue of an old road after a new alignment, and b) result of land consolidation or left-over spaces after planning. Moreover, Article 5, does not allow construction on narrow parts of parcels for three main reasons: a) the intent of visual clearance on street corners and intersections; $b$ ) to manage parcel densification; and c) to avoid transferring its odd forms into the volumetric of the buildings [5].

The surface areas of these non-constructible parcels (NCs) do not exceed $250 \mathrm{~m}^{2}$ depending on the zone they belong to and according to the zoning scheme introduced in 1973 by decree $n^{\circ} 5550$, which divides Beirut into 10 zones (Figure 1); as for their current land uses, they have various current temporary land uses such as parking lots for neighboring buildings, vacant plots, dumpsters, brown land, right-of-ways and so on. Some of them are illegally built and as for the un-built ones, they are rapidly being consolidated with larger adjacent plots by developers who are seeking more space for their projects [4].

Previous research has shown that unfiltered results for non-constructible parcels within Municipal Beirut add up to 6039. Zones 3 and 4 hold within their realm the highest number of nonconstructible parcels, having 2016 and 2008 parcels respectively. Zone 7 holds the lowest number with 115; Zone 2 with 534, zone 6 with 892 and finally zone 5 with 474 parcels [4]. Upon comparing these findings to previous Town Energy Balance (TEB) single layer urban canopy model [6] simulations for Municipal Beirut $[7,8]$, it was found that Zones 3 and 4 had the highest urban warming results, amongst which Bachoura district is situated.This therefore justifies the potential use of these existing non-constructible parcels for the purpose of urban cooling within Municipal Beirut.

The objective of this paper is to explore the potential of NCs to mitigate the urban air temperature specifically within the Bachoura district as a case study and then to project the positive findings to all other districts at the city scale. This approach is an innovative one within the context of Municipal Beirut. A numerical analysis is accordingly conducted using ENVI-met 4.0, which investigates the potential thermal cooling further to implementation of "cool surface materials" and urban vegetation in Bachoura. Cool materials are characterized by a high reflectivity or albedo $(\alpha)$ factor to the short-wave radiation and a high emissivity factor $(\varepsilon)$ to the long-wave radiation [9]. Changing the thermal property of surface materials of a city is the cheapest way to reduce the urban heat island effect [10]. Urban trees and vegetation also alleviate uncomfortably high urban thermal conditions of dense urbanized areaslike Beirut [11-15]. This paper accordingly proposes exploring the adequate parameters for implementation of these urban cooling mitigating measure preparing grounds for future implementation projects on selected NCs throughout Municipal Beirut.

Previous research (Figure 2) has shown that Bachoura district holds a total 197 NC parcels. Further studies have highlighted the exploitable parcels for the purpose of this paper, which are the vacant lands (VL) and right of ways (ROW). Vacant lands are the un-built lands of various uses such as brown land, junkyards or dumpsites, gardens, entrances for buildings, support for neighborhood generator or parking lots. Right of way are the un-built passages and movement corridors that lead to the inside of blocks. It was surveyed [16] that Bachoura holds $1307 \mathrm{~m}^{2}$ of VL and $1525 \mathrm{~m}^{2}$ of ROWs. Even though the surface area of right of ways is greater than that of vacant land of Bachoura, implementing "cool" materials or urban trees on them can be more challenging since they should also leave way for access to other parcels. 


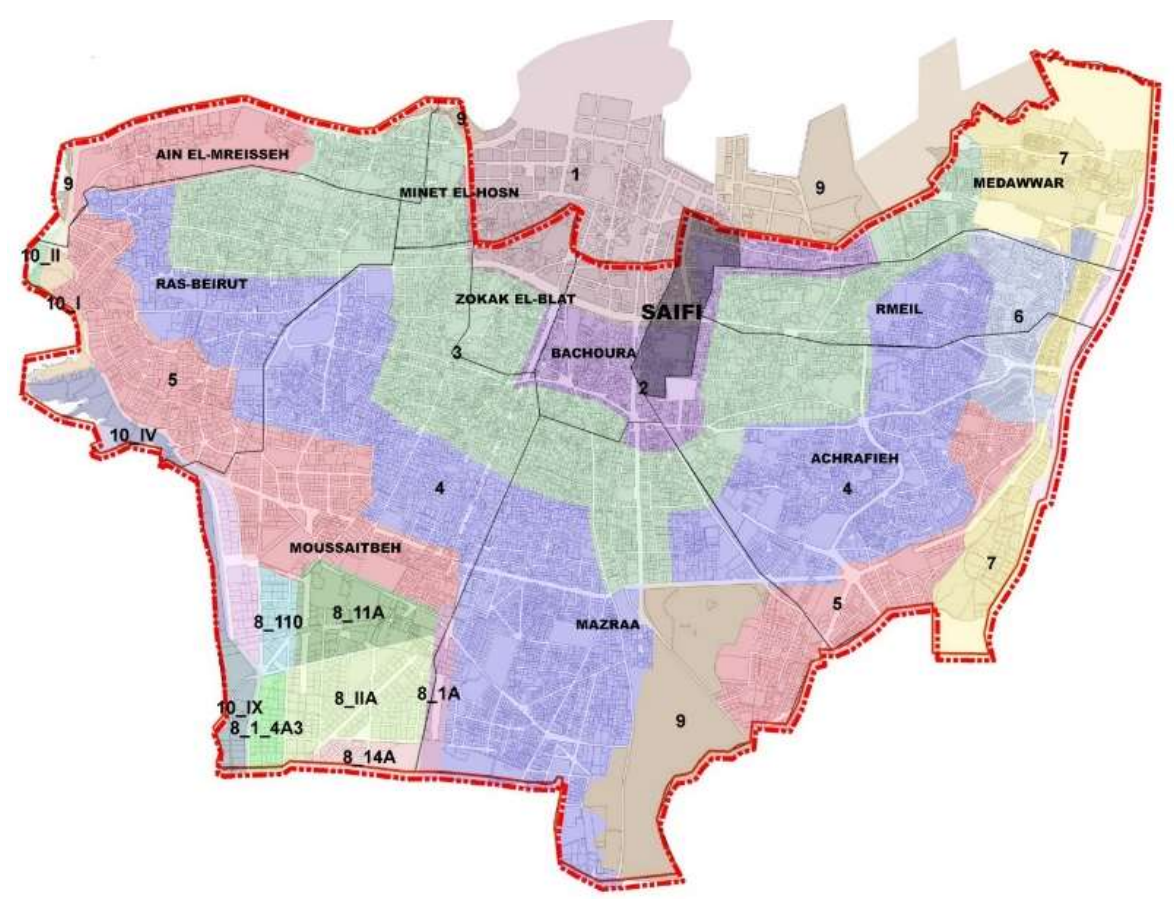

Figure 1. Municipal Beirut cadastral districts and zoning map

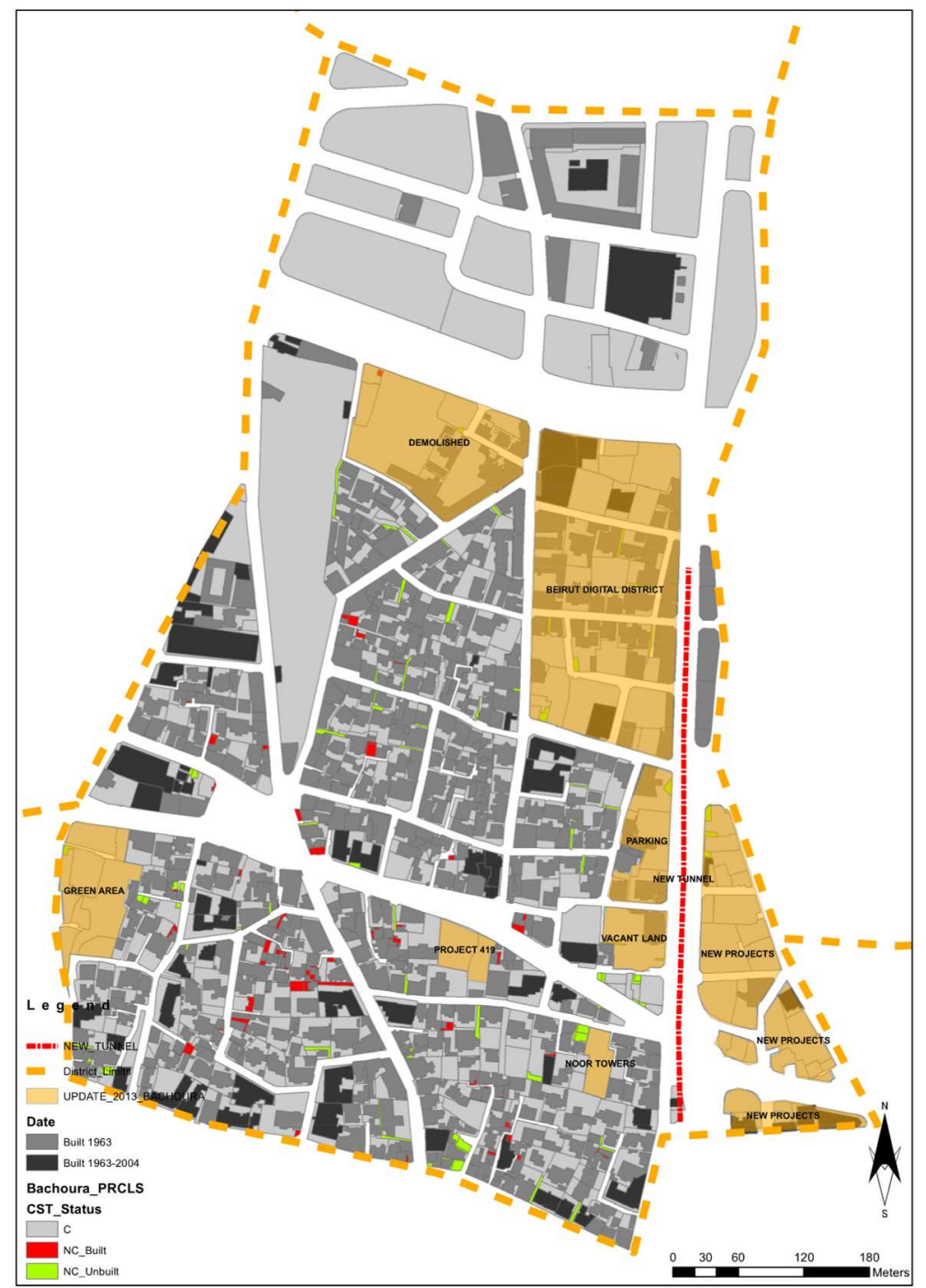

Figure 2. Non-Constructible parcels map within the Bachoura district [4] 


\section{Materials and Methods}

This section outlines the methodology applied for the purpose of this paper which includes: 1) the combination of NC and TEB data on Geograhical Informational System Software (ArcGIS) and 2) the input and preparation of the relevant data on ENVI-met 4.0 to conduct the simulations.

\subsection{Preparation of data on ArcGIS}

Data from previous findings for NCs as well as the thermal properties of dominating urban surfaces were combined and updated using Geographic Informational System Software (GIS) for Bachoura district. Data on each of the existing parcels was entered including plot number, surface area, and the physical and land-use nature. As for the thermal properties of dominating types of building and road surfaces, data for the albedo $\alpha$ and emissivity $\varepsilon$ values were defined based on the previous TEB data entry findings within a grid cell size of $200 \times 200 \mathrm{~m}$. All identified NCs within these grid cells were assumed to have the same thermal properties as those previously identified $[7,8]$. Table 1 below provides a sample presentation of the combined data including the town cover fraction defined by the building, road and garden fractions within each grid cell.

Table 1. Sample presentation of combined data for NCs and their thermal properties $[4,8]$

\begin{tabular}{|c|c|c|c|c|c|c|c|c|}
\hline District & $\begin{array}{l}\text { Plot } \\
\text { No. }\end{array}$ & $\begin{array}{l}\text { Surf. } \\
\text { Area } \\
\left(\mathrm{m}^{2}\right)\end{array}$ & $\begin{array}{c}\text { Constr } \\
\text { uctabili } \\
\text { ty } \\
\text { Status }\end{array}$ & $\begin{array}{l}\text { Nature } \\
\text { of Plot }\end{array}$ & $\begin{array}{c}\text { Dominating } \\
\text { building age } \\
\text { group, first } \\
\text { layer of bldg. } \\
\text { façade, roof } \\
\text { materials } \\
\text { and road } \\
\text { surfaces }\end{array}$ & $\begin{array}{l}\text { Albedo } \\
(\alpha) \text { of } \\
\text { first layer } \\
\text { in contact } \\
\text { with } \\
\text { ambient } \\
\text { air }\end{array}$ & $\begin{array}{c}\text { Emissivit } \\
y(\varepsilon) \text { of } \\
\text { first layer } \\
\text { in contact } \\
\text { with } \\
\text { ambient } \\
\text { air }\end{array}$ & $\begin{array}{c}\text { Town } \\
\text { Cover } \\
\text { Fraction } \\
\mathrm{s}\end{array}$ \\
\hline \multirow{7}{*}{$\begin{array}{c}\text { Bachour } \\
\text { a }\end{array}$} & 1261 & 78.6 & NC- & Vacant & $1948-1970$ & & & \multirow{7}{*}{$\begin{array}{c}\text { BLD }= \\
0.48 \\
\text { GDN }= \\
0.14 \\
\text { RD }= \\
0.38\end{array}$} \\
\hline & & & Unbuilt & Land & Beige/white & $\alpha=0.7$ & $\varepsilon=0.9$ & \\
\hline & & & & & paint \& & & & \\
\hline & & & & & plaster & $\alpha=0.225$ & $\varepsilon=0.805$ & \\
\hline & & & & & Grey dense & & & \\
\hline & & & & & $\begin{array}{c}\text { concrete roof } \\
\text { slab }\end{array}$ & & & \\
\hline & & & & & $\begin{array}{l}\text { Asphalt road } \\
\text { surface }\end{array}$ & $\alpha=0.2$ & $\varepsilon=0.97$ & \\
\hline
\end{tabular}

Based on the data presented in Table 1, it is seen that the town fractions surrounding the identified non-constructible parcels are primarily impermeable surfaces as opposed to natural surfaces that are associated with significant urban warming. Roads and buildings account for the majority of the town covers surrounding the identified NCs while gardens, which include predominantly high vegetation such as scattered urban trees or low vegetation like grass or bushes, account for the lowest town cover fraction thus emphasizing the deficiency of these important urban cooling spaces within the city. Dominating roof surfaces, comprised primarily of grey concrete roof slab, have very low albedo or solar reflectivity properties where $\alpha$ is 0.225 . Moreover, road surfaces with topmost layer comprised of asphalt, also have a low $\alpha$ of 0.2 [17]. These low solar reflectivity properties of dominating town cover fractions have been shown to contribute to significant urban warming in Bachoura district $[7,8]$.

As such, implementation of the two aforementioned mitigating strategies are proposed within the context of Municipal Beirut Accordingly, the non-constructible parcels defined as vacant land, brownfields or dumpsters are selected for investigation. It is worth noting that the energy performance of buildings may also be potentially affected as a result of the transfer of these NCs thus further alleviating the urban warming of the city; it is possible that such newly designed NCs may 
serve as energy-saving pocket parks throughout the city. However, while this is not the main subject of this paper, this topic of research is recommended for future studies.

Figure 3 therefore shows the selected NCs within a previously defined TEB grid cell within the district of Bachoura. Table 2 defines the characteristics of these NCs in Bachoura with proposed types of light-coloured materials or reflective coatings and their respective albedos that can be used in this regard within the context of Municipal Beirut [18-20]; although ROWs are more challenging for implementation of these UHI mitigating schemes, they are included in the selection of NCs for the purpose of this paper, more specifically for implementation of "cool" materials. The type of urban trees proposed for UHI mitigation is of the ficus nitida species which is commonly found and planted decoratively throughout municipal Beirut.

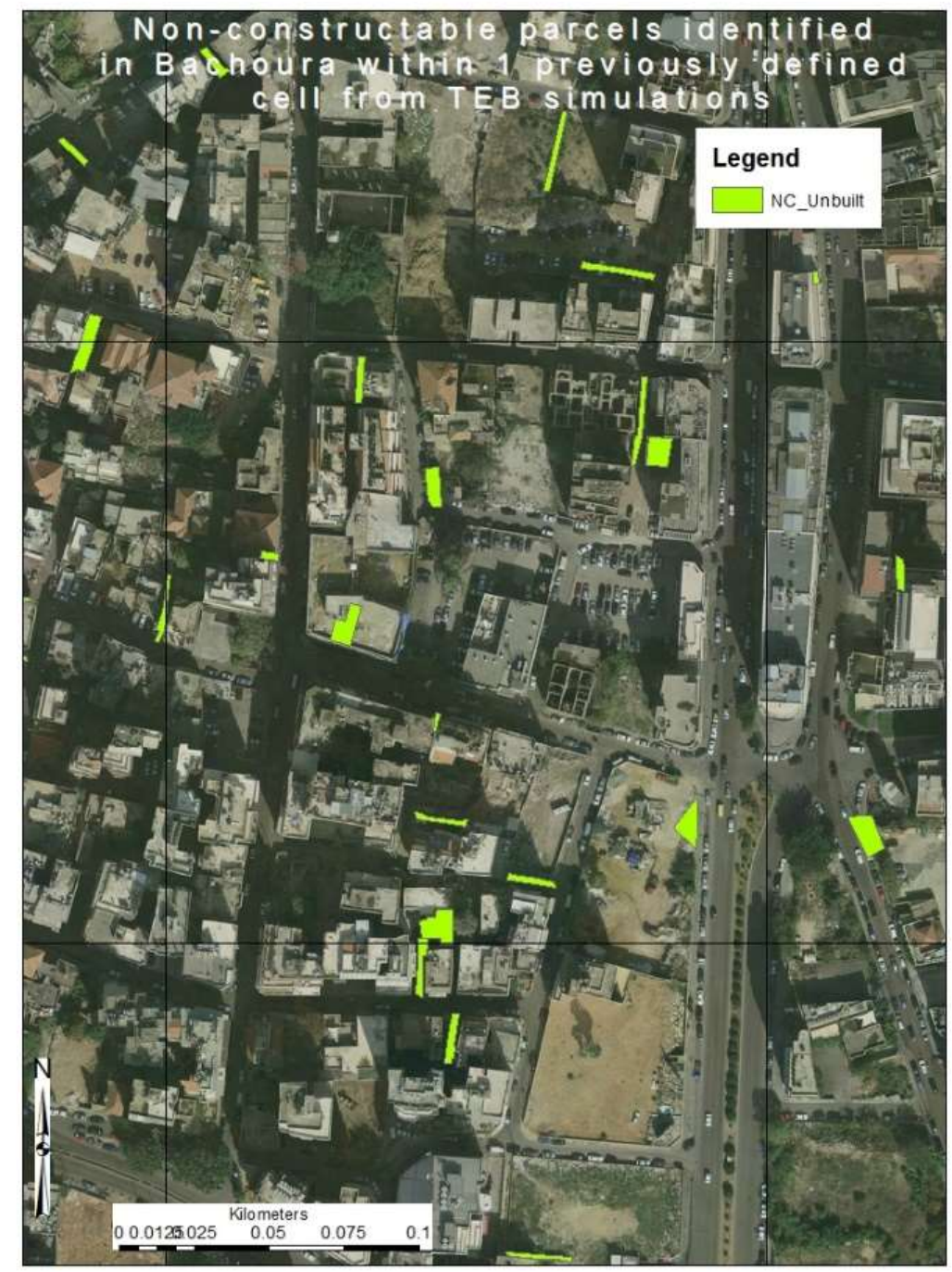

Figure 3. Non-constructible parcels identified in previous TEB cell(s) in Bachoura district

Table 2. Characteristics of existing NCs with proposed types of "cold" materials or reflective coatings and their thermal properties in Bachoura district

\begin{tabular}{|c|c|c|c|c|c|c|}
\hline $\begin{array}{l}\text { Plot } \\
\text { No. }\end{array}$ & $\begin{array}{l}\text { Surf. } \\
\text { Area } \\
\left(\mathrm{m}^{2}\right)\end{array}$ & $\begin{array}{c}\text { Nature of } \\
\text { Plot }\end{array}$ & $\begin{array}{l}\text { Existing } \\
\text { material }\end{array}$ & $\begin{array}{c}\text { Initial albedo } \\
\text { (adapted from } \\
\text { Oke, 1987) }\end{array}$ & $\begin{array}{l}\text { Proposed type } \\
\text { of "cold" } \\
\text { material or } \\
\text { reflective } \\
\text { coating [adapted } \\
\text { from } 1,9,21]\end{array}$ & $\begin{array}{c}\text { Final } \\
\text { albedo }\end{array}$ \\
\hline
\end{tabular}




\begin{tabular}{|c|c|c|c|c|c|c|}
\hline 706 & 97 & $\begin{array}{l}\text { Parking } \\
\text { Lot }\end{array}$ & Asphalt & 0.225 & $\begin{array}{l}\text { White alkyd } \\
\text { Chlorine rubber } \\
\text { coating }\end{array}$ & $0.5-0.6$ \\
\hline 707 & 46.64 & ROW & Pavestone & $0.2-0.35$ & $\begin{array}{c}\text { White acrylic } \\
\text { latex }\end{array}$ & $0.6-0.7$ \\
\hline 713 & 33.3 & ROW & Pavestone & $0.2-0.35$ & Marble & $0.45-0.5$ \\
\hline 724 & 30.1 & ROW & Pavestone & $0.2-0.35$ & Marble & $0.45-0.5$ \\
\hline 736 & 68.2 & $\begin{array}{l}\text { Parking } \\
\text { Lot }\end{array}$ & Asphalt & 0.225 & $\begin{array}{c}\text { White acrylic } \\
\text { latex }\end{array}$ & $0.6-0.7$ \\
\hline 1213 & 14.7 & $\begin{array}{l}\text { Vacant } \\
\text { Land }\end{array}$ & Bush/Garden & 0.18 & Marble & $0.45-0.5$ \\
\hline 1219 & 36.75 & ROW & Pavestone & $0.2-0.35$ & Marble & $0.45-0.5$ \\
\hline 1261 & 78.6 & $\begin{array}{l}\text { Parking } \\
\text { Lot }\end{array}$ & Asphalt & 0.225 & $\begin{array}{l}\text { White alkyd } \\
\text { chlorine rubber } \\
\text { coating }\end{array}$ & $0.5-0.6$ \\
\hline 1282 & 57.4 & Generator & $\begin{array}{l}\text { Concrete } \\
\text { Slab }\end{array}$ & $0.10-0.35$ & $\begin{array}{l}\text { White alkyd } \\
\text { chlorine rubber } \\
\text { coating }\end{array}$ & $0.5-0.6$ \\
\hline 1287 & 53.8 & Bush & Bush & 0.18 & $\begin{array}{c}\text { White acrylic } \\
\text { latex }\end{array}$ & $0.6-0.67$ \\
\hline 1378 & 34.6 & $\begin{array}{l}\text { Parking } \\
\text { Lot }\end{array}$ & Asphalt & 0.225 & Marble & $0.45-0.5$ \\
\hline 1392 & 74.2 & $\begin{array}{l}\text { Parking } \\
\text { Lot }\end{array}$ & Asphalt & 0.225 & $\begin{array}{l}\text { White alkyd } \\
\text { chlorine rubber } \\
\text { coating }\end{array}$ & $0.5-0.6$ \\
\hline 1486 & 9.1 & ROW & Pavestone & $0.2-0.35$ & Marble & $0.45-0.5$ \\
\hline
\end{tabular}

The total surface area of the above-listed NCs in the identified TEB grid is $634 \mathrm{~m}^{2}$ thus comprising approximately $1.6 \%$ of the total TEB grid area of $40,000 \mathrm{~m}^{2}$.

\subsection{Numerical Model}

The aim of the numerical analysis is to investigate the air temperature variation with the introduction of "cold" materials or reflective coatings in the existing NCs reported in Table 2. The simulation was carried out with ENVI-met 4.0 which is a transient tool able to recreate urban 3D models based on a soil-vegetation-atmosphere transfer scheme realized with deterministic equations that couple thermal and fluid-dynamics processes.

The target area taken into account is the Bachoura disctrict as seen in Figure 3, covering a surface area of approximately $130,000 \mathrm{~m}^{2}$ and the 3D domain used in ENVI-met is shown in Figure 4 . The selected NCs account for approximately $0.5 \%\left(650 \mathrm{~m}^{2}\right)$ of this chosen domain. The three-dimensional model recreates the distribution of structures, pavements and vegetation and it is composed by a mesh of $77 \times 105 \times 25$ square cells. Each cell has a dimension of $4(x) \times 4(y) \times 2(z)$ meters. 


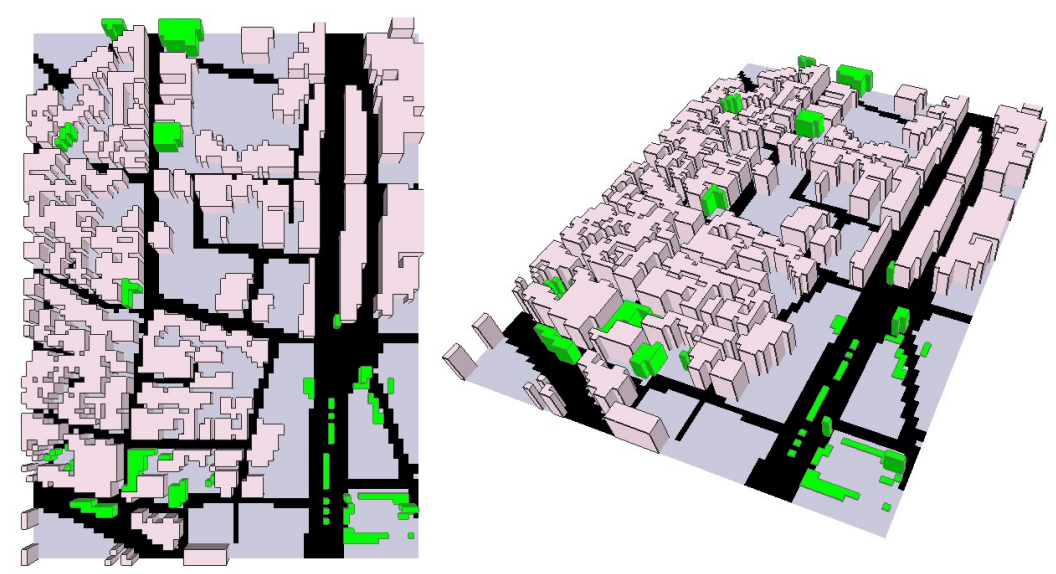

Figure 4. Three-dimensional computational domain of Bachoura district

\subsubsection{Model Validation}

The thermal conditions inside the Bachoura district are simulated on a typical summer day in Beirut. For this reason, a Bairut weather station in Fanar (placed at $1.8 \mathrm{~m}$ above the ground) was selected as representative of the mean air temperature condition in Beirut in 2011. The minimum, maximum and average air temperature in the summer of 2011 are shown in Figure 5.

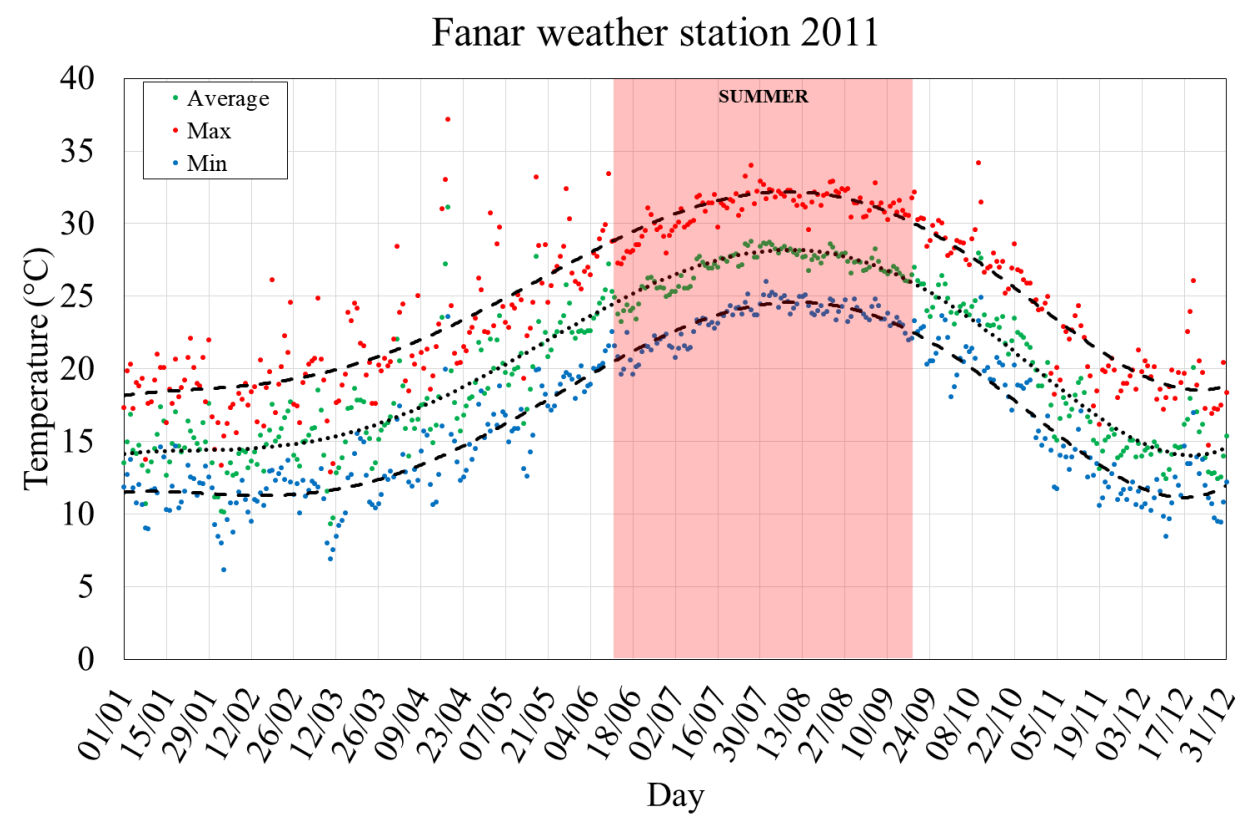

Figure 5. Minimum, maximum and average air temperature in the summer of 2011 of Fanar weather station

In order to validate the numerical model, a comparison was carried out between the maximum air temperature recorded at $1.8 \mathrm{~m}$ above the ground in the entire numerical domain and the maximum air temperature of $31.22^{\circ} \mathrm{C}$ measured by the Fanar weather station in the summer of 2011. In order to reduce the error, the initial air potential temperature was varied at 2,500 $\mathrm{m}$.

Figure 6 shows the trend of the error between the measured and the model-predicted maximum air temperature for different initial potential temperatures of the atmosphere. As shown in Figure 6, the initial potential air temperature of $20{ }^{\circ} \mathrm{C}$ results in the minimum error of $+0.1 \%$. 


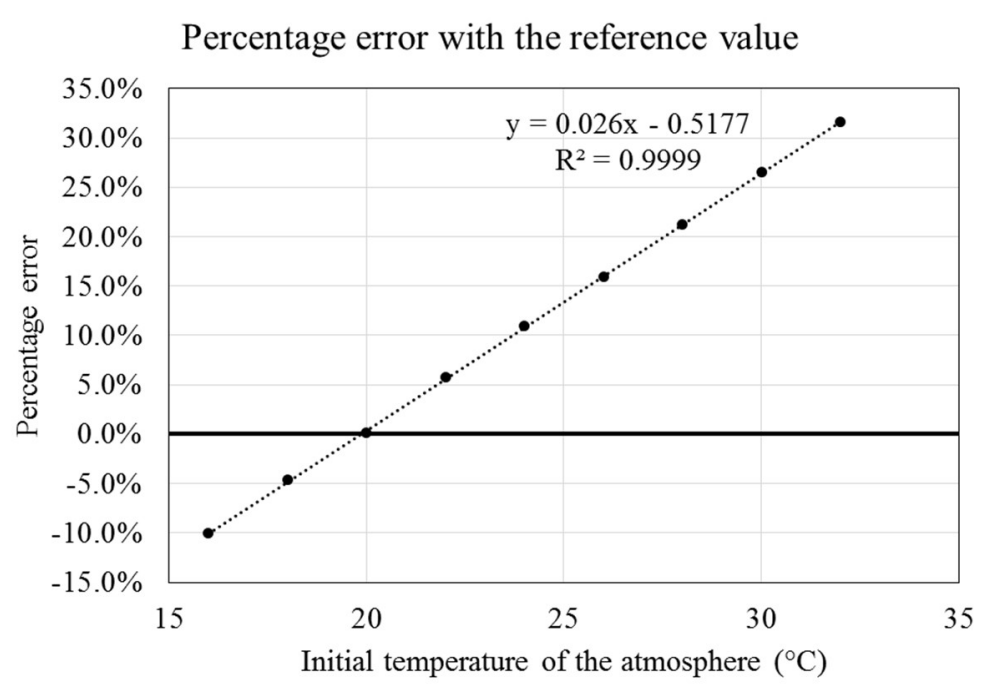

Figure 6. Trend of the error between the measured and the model-predicted maximum air temperature varying the model initial potential temperature of the atmosphere

\section{Results}

The recommended cooling measures were implemented in the selected NCs in Bachoura to conduct the simulations. In Table 3, the maximum air temperature difference from 0 to 5 meters above the ground between ante and 3 post-operam simulations are presented. These values correspond to the $2 \mathrm{pm}$ temperature because this is when the maximum air temperature differences are at their peak. The urban vegetation was placed only in 6 out of the 13 NCs listed in Table 2 since it was deemed preferable to place the trees in large spaces like parking lots; as such, right of ways were excluded from the simulations.

Figures 7 to 9 represent the simulation results that compare the ante-operam case with implementation of cool materials, then trees and then both cool materials and trees. The altitude air temperature variations reflect the first 5 meters above the ground because the analysis is emulating the feeling of populations.

The best mitigation effects are found in the NC number 736 because this is located relatively far from buildings with no shadow effects. On the other hand, NC 1282 with trees showed an increase in simulation results. The reason could be that, in this particular area the trees became an obstacle of the natural ventilation (see dSection 4 Discussions). Overall however, the maximum mitigation effects are seen with the use of 'cool' materials. 

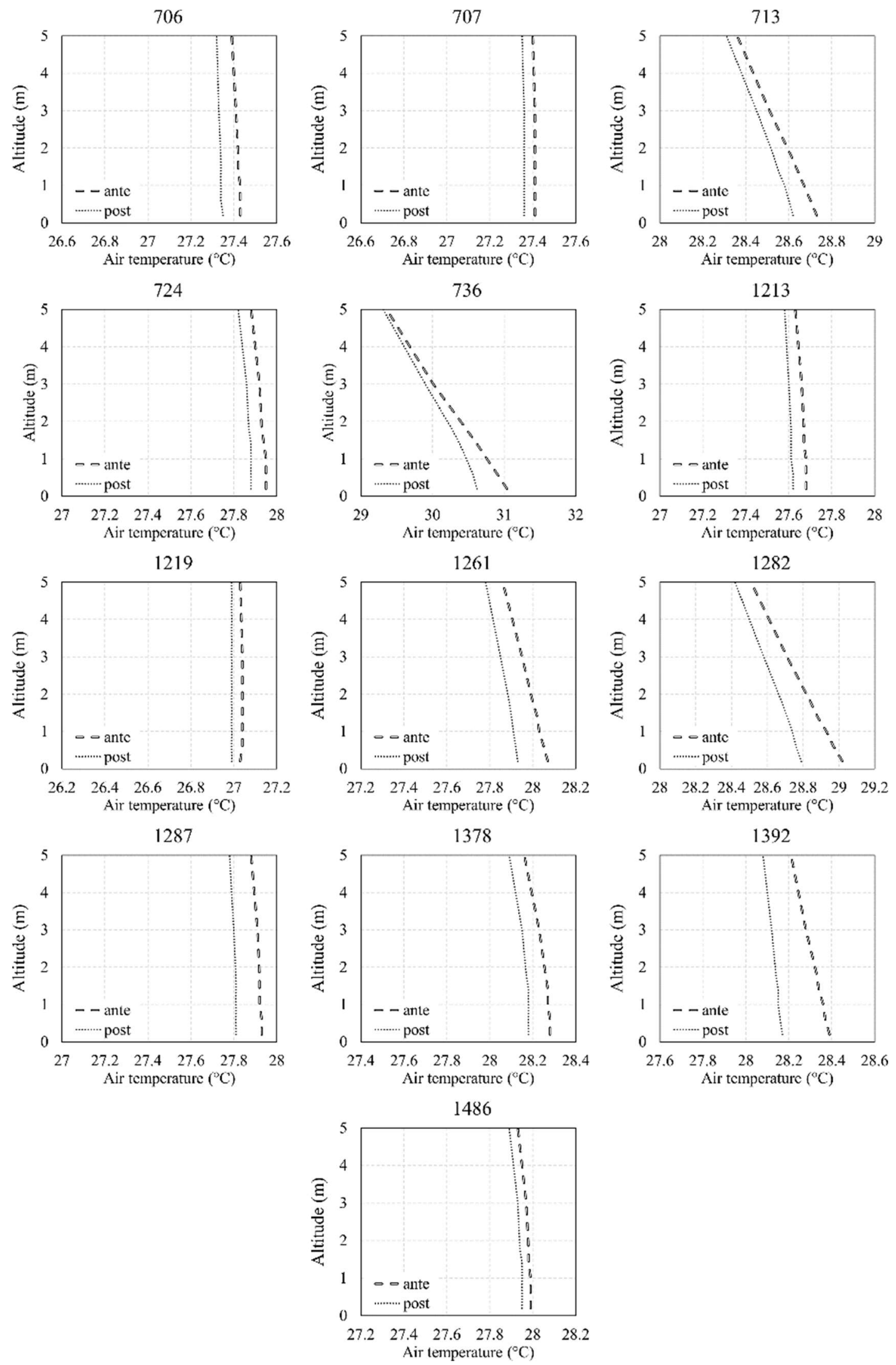

Figure 7. Altitude air temperature variations from ante to post-operam with cool materials 

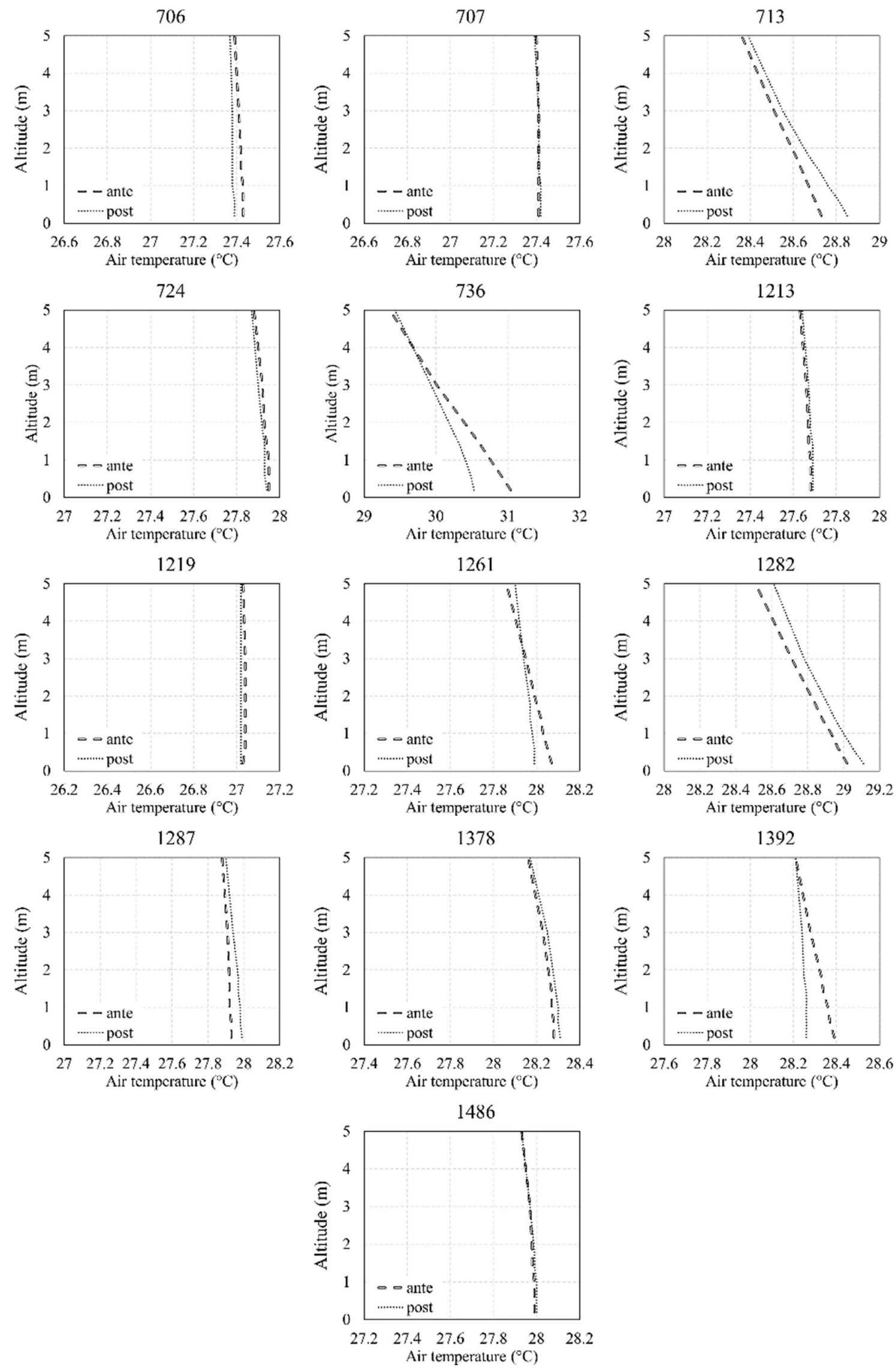

Figure 8. Altitude air temperature variations from ante to post-operam with trees 

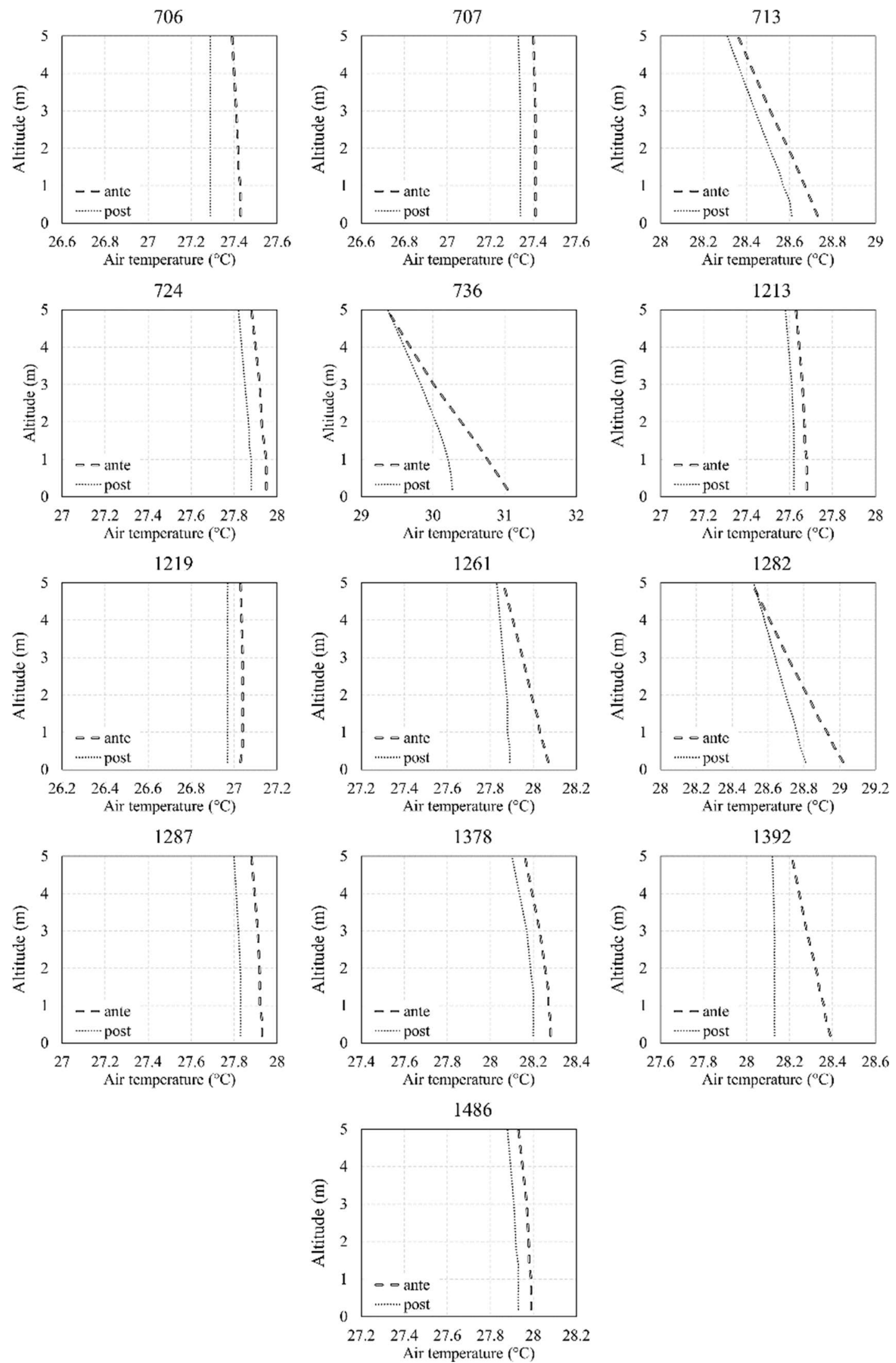

Figure 9. Altitude air temperature variations from ante to post-operam with cool materials and trees 
Table 3. Results of simulations for selected NCs in Bachoura district Maximum air temperature difference from altitude 0 to 5 meters between ante and post operam $\left({ }^{\circ} \mathrm{C}\right)$

$\begin{array}{ccccccccccccccc} & 706 & 707 & 713 & 724 & 736 & 1213 & 1219 & 1261 & 1282 & 1287 & 1378 & 1392 & 1486 & \text { Max } \\ \text { Cool } & -0.09 & -0.05 & -0.11 & -0.07 & -0.42 & -0.07 & -0.05 & -0.14 & -0.23 & -0.12 & -0.10 & -0.22 & -0.44 & -0.42 \\ \begin{array}{c}\text { mat. } \\ \text { Trees }\end{array} & -0.05 & +0.01 & +0.12 & -0.02 & -0.51 & +0.02 & -0.02 & -0.08 & +0.10 & +0.06 & +0.03 & -0.13 & +0.01 & -0.51 \\ \begin{array}{c}\text { Cool } \\ \text { mat. }\end{array} & & & & & & & & & & & & & & \\ \quad \mathcal{E} & -0.14 & -0.07 & -0.12 & -0.07 & -0.77 & -0.06 & -0.07 & -0.18 & -0.21 & -0.10 & -0.08 & -0.26 & -0.06 & -0.77\end{array}$

\section{Discussion}

"Cold" or light-coloured surface materials in urban environmental planning contribute to lower surface temperatures that affect the thermal exchanges with the air. Such surface materials reduce the amount of solar radiation absorbed by the building envelopes and urban structures and keep their surfaces cooler [9]. The use of appropriate materials to reduce urban heat islands to improve thermal comfort levels of urban environments has gained much interest in recent years [13]. This is because the mitigation and cooling potential of cool surfaces is significant and can highly contribute to decreasing temperatures in the urban environment [1]. Studies for commonly used coatings used in urban environment's external surfaces such as building walls and roofs, sidewalks, pavements, and parking lots showed that white acrylic latex and white alkyd chlorine rubber coatings had maximum temperature decreases [21]. Marble tiles also performed well with coldest recorded temperatures in comparison to concrete, asphalt and pebble [9]. Urban trees and vegetation also alleviate uncomfortably high urban thermal conditions of especially hot arid or semi-arid dense urban cities like Beirut [11-15].

In general, results of the simulations using ENV-met showed that the best mitigation measures can be achieved when using "cool" materials. Using trees showed positive as well as negative UHI effects for the case of Bachoura district. The reason for this could be that trees could obstruct summer breezes if not strategically placed thus having the reverse desired effect [22]. In fact, trees are perturbation of the thermo fluid-dynamics conditions because they are obstacle of the natural ventilation which can accordingly cause a variation of the micro-climate near the trees and in the rest of the domain. It is therefore suggested to have more in-depth knowledge of the plant species and their strategic placement within the NCs proposed as such.

To successfully intervene on such lands as described above in Municipal Beirut, and to develop a pilot project based on these previous findings, different types of strategies could be developed. One strategy is a user driven tactical strategy where UH mitigation programs are applied as part of a longterm vision for regeneration, and implemented with adequate resources such as the NDSM project in Amsterdam [23], and The High Line Project in New York [24].

Another tactical strategy would be based on the idea of "best practice approach" [25] where local temporary projects are taken as a model for broader policy-making and subsequent implementation. This type of strategy usually uses intermediary agents to find short and medium-term uses for vacant land, disused, or awaiting redevelopment land. In this strategy, applied in the Meanwhile London Project [26], temporary uses, should they succeed, could become permanent.

There are other strategies where temporary uses are applied in an event-like manner, and where long-term vision is coupled with limited resources. These project-based strategies, such as the Leipzig plantation project [27], are very important in triggering a more sustained strategy. These event-like projects can attract potential investors and provide resources for future projects, hence move towards a strategy of the first kind. Finally, there are the strategies, where power is kept centralized and no collaboration is envisioned. This strategy does not distribute resources for the implementation of temporary uses and reveals only partial understanding of potential benefits on the authorities' side and leave unclear the will to collaborate further. 
The above-mentioned urban strategies for the implementation of UH mitigation programs on residual parcels differ in their approaches, they all share the same understanding of the potential of $\mathrm{UH}$ mitigation programs as a catalyst for the regeneration of the city. Whether long or short-term strategies were envisioned; resources were or were not available; leaders were local authorities or intermediary agents; or developments were user driven pushing for collaboration or centralized, they all shared a bottom-up strategy starting with the understanding of user's needs and the acknowledgment of the potential of residual spaces/UHI mitigation.

In the case of Beirut, no specific urban strategy is modeled to integrate non-constructible parcels and implement UH mitigation programs. It will be important to define a strategy that embraces a long-term vision for the regeneration of the city, through the integration of these parcels and the implementation of UH mitigation programs. By acknowledging user's needs, finding resources and encouraging collaboration with involved actors, the developed user oriented strategy will have better chances of responding to the city's needs rather than becoming a strategy for punctual interventions.

\section{Conclusions}

Within Municipal Beirut, covering a total surface area of $20 \mathrm{~km}^{2}$, approximately 300,000 $\mathrm{m}^{2}$ of non-constructible parcels have been identified [11]. Within the context of resilient cities, there is significant potential for re-naturalization of these NCs by implementation of green and "cool" urban designs. For the purpose of this paper, numerical analysis using ENVI-met 4.0 was used to study the implementation of "cool" surface materials and urban trees as a sustainable strategy for mitigation of the urban temperature in Bachoura district. The total surface area of NCs in Bachoura is $2832 \mathrm{~m}^{2}$ however only $0.5 \%$ of the NCs in the Bachoura domain were used for the purpose of this paper; in addition whileright of ways were not deemed suitable for the simulations with trees due to the nominal spaces available for planting, they were used for the simulations with cool materials..

Implementation of "cool" design approaches in selected non-constructibles in a previously defined TEB grid cell [8] in the district of Bachoura showed best mitigation results with reductions in urban temperatures of up to $1 \mathrm{~K}$, while implementation of trees showed mixed results as trees can obstruct natural ventilation thus calling for the need for further and more in-depth studies of plant species in this regard. The objective of this paper is to implement these positive findings in the identified NCs throughout the administrative boundary of Beirut in collaboration with the Municipality and other potential funding agencies.-This research is considered a milestone for the case of Beirut as it provides evidence of the importance of making use of these NCs for multiple objectives including beautification of the city, providing a 'breathing' space for the local communities and building a more resilient city within the context of climate change and the urban heat island.

Finally, it is worth noting that the urban heat island also has an important adverse impact on the energy consumption of buildings and increases their energy consumption for cooling purposes [1]. Experimental designs are in the process of being developed with relevant parties which aim to implement proposed "cool" design strategies in the identified NCs at neighborhood scale to analyze the effects of these designs on the energy consumption and efficiency of buildings and accordingly on the impact on the urban heat island phenomenon. Such campaigns can help to validate the results of this paper.

Conflicts of Interest: “The authors declare no conflict of interest."

\section{References}

1. Santamouris, M. (2013). Using cool pavements as a mitigation strategy to fight urban heat island-A review of the actual developments. Renewable and Sustainable Energy Reviews 2013, 26, 224-240.

2. UNFPA Lebanon. Available online: http://www.unfpa.org.lb/PROGRAMME-AREAS/Population-andDevelopment/Population-and-Development-Strategies.aspx (accessed on 14 September 2015).

3. Ministry of Environment / Lebanese Environment and Development Observatory (LEDO) / ECODIT. Lebanon State of the Environment Report. Available online: http://www.moe.gov.lb (accessed on 14 January 2018) 
4. Aouad, D. Urban Acupuncture as a tool for today's re-naturalization of the city: The non-constructible parcels of Municipal Beirut through the case study of Saifi district. Architectural Research addressing Societal Challenges. EAAE/ARCC. Da Costa, Roseta, Lages, da Costa (Eds.), Taylor \& Francis. Lisbon, Portugal, 2017.

5. El-Achkar, E. Réglementation et formes urbaines : le cas de Beyrouth. Beirut, Lebanon: CERMOC. 1998

6. Masson, V. A physically-based scheme for the urban energy budget in atmospheric models. Boundary-Layer Meteorology 2000, 94(3), 357-397.

7. Kaloustian, N., and Diab, Y. Effects of urbanization on the urban heat island in Beirut. Urban Climate 2015, 14, 154-165.

8. Kaloustian, N. On the Urban Heat Island in Beirut. PhD Thesis. Académie Libanaise des Beaux-Arts (ALBA), Balamand University and Université Paris-Est, Lebanon and France. 17 November 2015.

9. Doulos, L., Santamouris, M., \& Livada, I. Passive cooling of outdoor urban spaces. The role of materials. Solar Energy 2004, 77, 231-249.

10. Kleerekoper, L., van Esch, M., \& Salcedo, T. B. How to make a city climate-proof, addressing the urban heat island effect. Resources, Conservation and Recycling 2012, 64, 30-38.

11. Akbari, H., Pomerantz, M., \& Taha, H. Cool surfaces and shade trees to reduce energy use and improve air quality in urban areas. Solar Energy 2001, 70(3), 295-310.

12. Akbari, H. Energy Saving Potentials and Air Quality Benefits of Urban Heat Island Mitigation. Lawrence Berkeley National Laboratory, California, 2005.

13. Che-Ani, A.I., Shahmohamadi, P., Sairi, A., Mohd-Nor, M.F.I., Zain, M.F.M., \& Surat, M. Mitigating the urban island effect: some points with altering existing city planning. European Journal of Scientific Research 2009, 35(2), 204-216.

14. Oliveira, S., Andrade, H., \& Vaz. The cooling effect of green spaces as a contribution to the mitigation of urban heat: A case study in Lisbon. Building and Environment 2011, 46(11), 2186-2194.

15. Rosenfeld, A.H., Akbari, H., Romm, J.J., \& Pomerantz, M. Cool communities: strategies for heat island mitigation and smog reduction. Energy and Buildings 1998, 28(1), 51-62

16. Aouad, D. Non-constructible parcels within the boundaries of Municipal Beirut: The case study of Saifi, Bachoura and Zokak El-Blat. Thesis. Académie Libanaise des Beaux-Arts (ALBA), Balamand University, Lebanon, 2014.

17. Oke, T.R. Boundary Layer Climates, second ed. Routledge, London, 1987

18. Santamouris, M. (Ed.), Energy and Climate in the Urban Built Environment. James \& James Science Publishers, London, 2001

19. Asaeda, T., Ca, V.T., Wake, A. Heat storage of pavement and its effect on the lower atmosphere. Atmos. Environ. 1996, 30 (3), 413-427.

20. Taha, H., Sailor, D., \& Akbari, H. High albedo materials for reducing cooling energy use. Lawrence Berkeley Lab Rep. 31721, UC-350, Berkeley, CA, 1992.

21. Synnefa, A., Santamouris, M., \& Livada, I. A study of the thermal performance of reflective coatings for the urban environment. Solar Energy 2005, 80(8), 968-981.

22. Gago, E. J., Roldan, J., Pacheco-Torres, R., \& Ordóñez, J. The city and urban heat islands: A review of strategies to mitigate adverse effects. Renewable and Sustainable Energy Reviews 2013, 25, 749-758.

23. Andersson, L. Urban Experiments and Concrete Utopias: Platform 4 a 'Bottom Up Approach to the Experience City'. Aalborg University, Department of Architecture and Design, Denmark, 2008.

24. NYC Parks. Available online: http://www.nycgovparks.org/parks/highline (accessed on March 24, 2014)

25. Lehtovuori, P., \& Ruoppila, S. Temporary uses as means of experimental urban planning. University of Turku, Estonian Academy of Arts. Estonia: Estonian Academy of Arts, 2012.

26. Killing Architects. Urban tactics: Temporary interventions + long term planning. Available online: http://www.killingarchitects.com/urban-tactics-final-repor/ (accessed on May 22, 2013)

27. Interim Use: Opportunity for New Open-Space Quality in the Inner City - The Example of Leipzig. By Heck, A., \& Will, H. Available online: http://www.difu.de/node/5959 (accessed on 16 January 2014) 